\title{
Mannerism, Modernity and the Modernist Architect, 1920-1950
}

Dirk De Meyer

Ghent University

Author Posting. (c) The Journal of Architecture, 2010.

This is the author's version of the work. It is posted here by permission of 'Copyright Holder' for personal use, not for redistribution.

The definitive version was published in The Journal of Architecture, Volume I 5 Issue 3, June 2010.

doi:I0.1080/| 3602365.2010.486565 (http://dx.doi.org/| 0.1080/| 3602365.2010.486565)

Introduction

Criticized for its artifice and stylization, and loaded with negative connotations as manieroso, the art of the sixteenth century nevertheless became, in the 1920s, a new historical and stylistic periodization and an intensely studied subject. Some aspects of that construction of Mannerism as a distinct category are intimately linked to the contemporary development of modernity, and modernism. Mannerism's 'discovery' was closely related to pioneering developments in art and architecture. Furthermore, while Mannerist art was offering up captivating case studies, research on Mannerism adapted models from psychoanalysis, which was maturing in those same years and was crucial to understanding the structure of the modern self and of modern society. Finally, as we will show, the resulting image of the Mannerist architect was seminal in the styling of the figure of the new, modernist architect.

Breaking up the Renaissance

The creation of Mannerism was part of the fine-tuning of the historical and stylistic periodizations, of the gradual breaking up into distinguishable phases of that amorphous 'classical period' that for Jules Michelet, in Histoire de France (1855), and for Jacob Burckhardt, in Die Kultur der Renaissance in Italien (I860), had stretched from the dawn of the Renaissance to the eighteenth century. The first step had been Cornelius Gurlitt's series of books, started in 1883, on Baroque and Rococo Architecture.' Yet internationally more influential was Heinrich Wölfflin's introduction, in 1888, of the 'Baroque' as a stylistic category, apart from the Renaissance, in his Renaissance und Barock. This book, published only two years after his graduation, would make Wölfflin famous even before his twenty-fifth birthday and would introduce the Baroque as a serious area of study. With perfect feeling for the Zeitgeist of the Apollonian-Dionysian dualism of Friedrich Nietzsche's Die Geburt der Tragödie (I87I), the book introduced the seminal distinction between the 'classical' Renaissance art and the 'anti-classical' Baroque. 
For Wölfflin, the part of sixteenth-century art that we now describe as Mannerist was (still) contained within that larger, Baroque period - which as a consequence starts a century earlier for Wölfflin than for us today. It also remained that part that Burckhardt before him, as well as most French and English-speaking scholars for a generation thereafter, dismissed as degenerate. In Renaissance und Barock, Wölfflin called Villa Giulia "abnormal" and "lacking of character". 2 Mannerism might even be bad for your health: "All the most prominent baroque [i.e. Mannerist] artists suffered from headaches." In his later Kunstgeschichtliche Grundbegriffe (1915) Wölfflin even excluded the troublesome Mannerists, who refused to fit nicely into his categories. Even when Riegl in his studies of late-Roman art (190I) and of Baroque art (1908, posthumously) had argued that the art of supposedly decadent periods could be interpreted in terms of positive, although non-classical, expressive purposes, it would take at least another decade and a half to realize such a reinterpretation. ${ }^{4}$

\section{Expressionist Mannerism: Dvorák’s El Greco}

Probably the first to present Mannerism in a non-deprecating waywas Max Dvorák in his 1920 lecture 'Über Greco und den Manierismus', which was later published in his Kunstgeschichte als Geistesgeschichte (1924). ${ }^{5}$ As is clear from its title the lecture dealt with the Spanish painter of Greek origin, Doménicos Theotokópoulos, who had been in contact with Venetian and Roman Mannerist art before establishing himself in 1577 in Toledo. The El Greco text is particularly important to us because, through the case of El Greco, it evidences Dvorák's aims to clarify ideas about Mannerism in a more general sense.

For Dvorák a new appreciation of El Greco is favored by the conditions of the time. The world in which he introduces El Greco has just come out of the first technological war. Its rational, scientific bases are being challenged by a new utopian humanistic and spiritual solidarity. It is the world of Ernst Bloch's Geist der Utopie (1919), of the crystalline architectural fantasies of Bruno Taut, of German expressionism and the first Bauhaus manifesto, illustrated with Lyonel Feininger's expressionist cathedral wood-cut.

Not many words are needed to explain why Greco was bound to be increasingly forgotten in the subsequent centuries, the centuries dominated by natural science, materialist thought, belief in causality and technical progress, when civilization was a matter of mechanization, of eyes and brain but no heart. Today this materialist civilization is approaching its end. [...] [L]iterature and the arts have turned towards spiritual absolutes, as they did in the Middle Ages and in the period of Mannerism and have turned their backs on sensuous nature. [...] In that eternal struggle between matter and spirit, the scales are inclining towards a victory of the spirit, and it is to this turn of events that we owe our recognition of Greco as a great artist and prophetic mind whose glory will come to shine brightly. ${ }^{6}$

Only man in the immediate post-war period is, again, able to understand El Greco and Mannerism because he is part of a time that sees the end of positivism, the end of a long 
secular nineteenth century, and because he is about to enter a new, utopian and spiritual era. Dvorák's argument contains a double legitimation: a historical period is legitimizing the present; but also: a hitherto unappreciated period in the arts can only now be properly recognized on the basis of current conditions.

The Czech art historian speaks of an art on the verge of religious hallucination and he sees in its subjective and expressionistic intentions the manifestations of a "spiritual crisis". 7 The basis for this upsurge is, for Dvorák, the spiritualism of the late Michelangelo, the Michelangelo of the Last Judgement and of the late Pietà. Dvorák shows us a fascinating, non-mathematical era that followed the mathematical Renaissance - an era the ambitions of which seem naturally linked to an important part of European, in particular German, developments in architecture and the arts. It is, moreover, remarkable how the study of (Italian) Mannerism is, during the interwar period, a nearly exclusively German preoccupation - in total absence of contributions by Italian art historians, an absence which is paralleled with the scarcity of Italian contributions to expressionist art studies.

It is an expressionist Mannerism that is praised in those early years: in his inaugural lecture at the University of Freiburg, Walter Friedländer, in 1914, a year before Wölfflin's ostentatious ignoring of the artists of the 1520s in his Grundbegriffe, presented the period as the "Antiklassichen Stiles um I520", the anti-classical style around I520. Friedländer's text, subsequently published in 1925, praises the 'expressive' qualities of the early Mannerists, not by coincidence undervaluing, if not completely rejecting, the accomplishments of the mid-century painters. He considers their "dimaniera style", in contrast, "tedious and unbearable" in its repetition of forms taken from predecessors' styles. ${ }^{8}$ Yet, Friedländer introduces something else which will become crucial to the interpretation of Mannerism by architects: Mannerism is understood by Friedländer as a reaction against the High Renaissance's standardization and "objectivization" of beauty. Art becomes an "imaginative idea unsupported by imitation of nature" and a "rejection of the normative and the natural". ${ }^{9}$ What Friedländer saw — and what some modernist architects later intuited - was how, with humanism in a new phase, with the printing press modifying the conditions of access and debate, and with courtly society superseding republican, Renaissance ingenium had shifted toward something more individualized, something more 'modern'. As such manieria, that old Vasarian ideal, could suddenly become, far from tedious, desirable: "not only the trace of a particular hand and its inextricable habits, but an expression of a spiritual particularity" 10 - selfconfident, independent, and transgressing the dicta of mere rationality.

German historiography in the 1920s and 1930s would further destroy the homogeneity of the Renaissance while underscoring its irrational, contesting, surrealistic, popular and even abstracting qualities." Furthermore, what Dvorák (1922), Wilhelm Pinder (1923) and Friedländer (1925) observed in painting is simultaneously appreciated in architecture. Already in 1912 Friedländer had written in Das Kasino Pius des Vierten about anti-architectonic tendencies in some Mannerist architectonic experiments by artists versed in the figurative arts, such as Raphael, Baldassare Peruzzi or Pirro Ligorio, ${ }^{12}$ and soon Panofsky would use the category of architectonic Mannerism in a non-negative way in his 1919 essay on Bernini's Scala Regia, speaking about a Mannerism 
that oscillates between the classical and the anti-classical. ${ }^{13}$ Subsequently, Mannerism was shown to have affected architecture in a broader sense by Pinder's student Nikolaus Pevsner: in Gegenreformation und Manierismus, of 1925, he argued for the establishment of Mannerism as a separate style, and in his dissertation Leipziger Barock, published in 1928, he applies the concept of (hitherto painterly) Mannerism to architecture. ${ }^{14}$ It is followed by Panofsky's hypothesis of an autonomous Mannerist architecture in his study on the projects of Domenico Beccafumi for the Casa dei Borghesi in Siena in Das erste Blatt of 1930. ${ }^{15}$

By the early 1930s the conceptual categories and the 'expressionist' readings, introduced by Dvorák and Friedländer, have been fully transported to the study of Mannerist architecture, amongst others by Ernst Michalski, an assistant to Pinder, who underlines its liberating force and its opposition to classical (Renaissance) structurality and rule, and by Hans Hoffmann, who sees the classical equilibrium of Italian Renaissance replaced by fluid spaces bathing in an anti-naturalistic light. ${ }^{16}$ In an unmistakable parallel to the aims of at least part of the German architectural avant-garde, Mannerist escape, restlessness and irrationality opposes itself to academic rule and Beaux-Arts realism.

\section{The Prototypical Modern Architect: Burckhardt's and Le Corbusier's Michelangelo}

The appearance, as one of the outcomes of the First World War, of the utopianhumanistic-spiritual architect, forging buildings into the crystalline and 'Alpine' structures of German expressionism was soon accompanied, throughout Europe, by another figure. In a move that had started in the nineteenth century, as Alina Payne has argued,

architecture gradually embraced the world of science and technology, so that by the 1930s, to the image of the engineer as culture hero, modernist critics and theoreticians like Sigfried Giedion held up a refashioned architect who had left the world of the Beaux-Arts behind and inhabited that of the social sciences, environmental and urban planning, and industry. ${ }^{17}$

One of the books that would soon be considered an embodiment of this tendency was Le Corbusier's Vers une architecture, published in 1923, the same year as the construction of Maison La Roche in Paris. However, the well-known and over-published pages of the chapter "Des yeux qui ne voient pas ...", with their illustrations of cars, steamships and air planes, are followed immediately by pages, rarely mentioned in later commentary, devoted to "La leçon de Rome" — a lesson delivered in three parts: Antique Rome, Byzantine Rome and ... Michelangelo.

Michelangelo is the only architect Le Corbusier mentions by name in a positive sense (other than himself) and the words could hardly express a stronger admiration: "MichelAnge est l'homme de nos derniers mille ans comme Phidias fut celui du précédent millenaire." 18

Already some sixty years earlier Burckhardt had identified Michelangelo, in Kultur der Renaissance in Italien, as the prototypical modern artist-because in Michelangelo 
creation had become individual expression. For the Swiss historian this was not a laudable thing: it was a process that threatened the balance of energy and order, of individuality and shared values and assumptions on which, in his view, the special beauty of Renaissance art rested. For Burckhardt, this new artist used art, not as a vehicle to represent subject matter, as had been the case with earlier societies, but as a medium to work through the artist's own spirit and angst-a process that occurred frequently, according to Burckhardt, at the cost of the quality of the art. ${ }^{19}$

What Burckhardt regards as a problem in Michelangelo-and in Mannerist artists in general — is, on the other hand, exemplary for Le Corbusier: "L'oeuvre de Michel-Ange est une création, non une renaissance (...)" and, in the bald formulation typical of the French master: "Tel homme, tel drame, tel architecture." ${ }^{20}$ Whereas for Burckhardt in his study of the Renaissance there was no space left for personal deformations - hence his interpretation of Michelangelo's ricetto as "evidently a joke by the great master", it is exactly by "the Mannerist excess and conflict of this building that [Le Corbusier] is most deeply moved", as Colin Rowe would note twenty years later. ${ }^{21}$ That could be so, since Michelangelo's anti-classicism came close to Le Corbusier's own fight. Michelangelo's Saint Peter's, which Le Corbusier had discovered during his 1921 tour, meant to the Frenchman what early Mannerist painting meant, in those same years, to German expressionists: a reaction against both Academic art officiel and Impressionism. "Is it surprising," Gombrich later observed, "that they saw in the rejected alternative of Mannerism the predecessor of an anti-realistic and anti-idealistic modern art, maligned as their friends were maligned?"22

While around 1920 many architects still saw in Mannerist buildings an appalling protobaroque, a "willekeurige kunstsoort", an art form based on arbitrariness, a "pest" and an "epidemical illness", as Theo Van Doesburg would comment in his Klassiek-Barok-Modern (19|8), ${ }^{23}$ clearly some others, like Le Corbusier, detected something else: an epoch "curiously reproducing contemporary patterns of disturbance". ${ }^{24}$ This would allow Le Corbusier, having discovered in the engineer "our Louis XIV", ${ }^{25}$ to find in a cinquecento artist a prototype for the modern architect.

\section{Freudian Mannerism: Gombrich's Giulio Romano}

While Dvorák's quintessential mannerist was El Greco, Ernst Gombrich, in his dissertation work of the early 1930s under the direction of Julius von Schlosser at the University of Vienna — the famed Vienna School—identified Giulio Romano as the epitome of Mannerism, and extended what he considered as the main characteristics of his architecture to Mannerism as a whole. In line with his fellow art historians, ${ }^{26}$ he saw an art of conflict with the canon, an anti-classical art-the terms 'Mannerist' and 'anticlassical' become almost interchangeable in the 1920s and early 1930s, as Wolfgang Lotz would later remark. ${ }^{27}$ Yet in Giulio, Gombrich also found an art that tended towards dissolution rather than construction.

In 1934 and 1935, Gombrich published the results of his research in a lengthy two-part article entitled 'Zum Werke Giulio Romanos', in the Jahrbuch der Kunsthistorischen 
Sammlungen in Wien. The first part deals exclusively with Palazzo del Tè; the second aims at contextualizing the building. ${ }^{28}$ Gombrich would later, in an interview, recall the following about this period:

When I first visited Mantua as a student my head was full of debates about the status and meaning of 'Mannerism' in sixteenth-century art. Being startled by the Palazzo del Tè I was surprised to find that it had not yet been mentioned in these discussions and that in particular Giulio Romano's building designs had been completely neglected. This was before Rudolf Wittkower had published his seminal paper of 1934 on the Laurenziana as a document of Mannerist aesthetics, and the question whether or not the term Mannerism could be usefully applied to architecture was still sub judice. [...] I found to my satisfaction that much of what I had read about the alleged anti-classical style applied to many of Giulio's bizarre designs, while others seemed to me to be almost ostentatiously restrained and classical. I made much of this tension and of what it appeared to signify in psychological terms, though I explicitly rejected the recourse to the 'spirit of the age' as an explanation of these characteristics. ${ }^{29}$

Applying psychological insights to the study of Kunstgeschichte had been done by others, not the least by Riegl, Wölfflin and Wilhelm Worringer, but the central difference between Gombrich and these other historians is the degree to which he was prepared to expose the psychological assumptions on which his work had been based. ${ }^{30}$ Gombrich enters Giulio's work through the study of his intimate, personal emotions. Manfredo Tafuri once observed how these try to come to the fore, but cannot find expression in a language controlled by the finito, the concinnitas and the ideals of Renaissance harmony. "Precisely the poetics of collapse, of the 'non-finito', of ambiguity, were, for Gombrich, the uttering of the intensification of the subjective emotions, which, however, crash with the codex." ${ }^{31}$ Gombrich's Palazzo del Tè is the product of that collision between a subject, Giulio, and a discipline, architecture.

There is hardly any need to recall that Gombrich is making these analyses in the Vienna of Freud, in the years following the publication of Das Unbehagen in der Kultur (1930). Central in that book is the fundamental tensions between civilization and the individual, a friction that has its origin in the clash between the individual's quest for instinctual freedom and civilization's contrary demand for conformity and the repression of those same instincts. As Kurt Forster and Richard Tuttle noted in their 197I study of the Palazzo del Tè, Gombrich

revealed a 'conflict' among its members which he characterized as suspended in psychological deadlock. He connected the powerful contrast between the refined architectural details and the coarse rustica features in Giulio's building with Serlio's later interpretation of these elements as a contrast between the work of 'artifice' and the work of 'nature'. Furthermore, he persuasively associated this duality with the modern psychological terms of reason and libido. ${ }^{32}$

What is more, Freud had written on art-or better: on artists. In 1914 he had (anonymously) published his famous article on The Moses of Michelangelo, essentially 
aiming to discover the artist's personal motivation behind the sculpture. In 1910 he had exposed his method in his first (and favorite) study concerned with art: Eine Kindheitserinnerung des Leonardo da Vinci (translated as Leonardo da Vinci; a Psychosexual study of a Childhood Reminiscence). Therein he reconstructs his subject's past, discovering possible complexes, repressions, and neuroses. The artist is treated as a patient and his products are analysed in terms of these psychological considerations. The artwork is seen as a means of giving expression to, or dealing with, various psychic pressures. ${ }^{33}$

Psyche rather than Zeitgeist_-or: Freud, rather than Hegel/Burckhardt/Wölfflin: Gombrich became well-versed in psychoanalysis, first through the lectures of the psychologist and semiotician Karl Bühler, then through his collaboration with his fellow student and friend Ernst Kris, a Viennese art historian turned psychoanalyst. ${ }^{34}$ In 1922, Kris had written his dissertation, also under Schlosser, examining the interrelationship between Renaissance art and science within two Mannerist artists or craftsmen, the French sixteenth-century potter Bernard Palissy and the German etcher and goldsmith Wenzel Jamnitzer. By 1933 Kris had become an editor of Imago: Zeitschrift für psychoanalytische Psychologie, ihre Grenzgebiete und Anwendungen, a journal of applied psychoanalysis edited by Freud. ${ }^{35}$ He practiced psychoanalysis on his own and through the 1930s he intensely investigated the role of the unconscious in the artistic process. ${ }^{36}$

In this context a new approach to Mannerism opened, in some ways parallel to, but even gradually replacing, the 'expressionist' approach: the view that describes Mannerism as the result of inner tensions, anxieties, neuroses and alienation, the 'Angst Mannerism' as James Mirollo would later coin it. ${ }^{37}$ The self-reflexivity so characteristic for Mannerist art was ready to be interpreted in terms of narcissism. Such paintings as Agnolo Bronzino's Lucrezia Panciatichi (ca. 1540)—of whom Henry James had written in The Wings of the Dove (1902), "splendid as she is, one doubts if she was good"-may from now on seem to be created for psychological readings of those characteristic stiff postures: the strain in the facial muscles from now on suggesting underlying tensions, even despair, beneath the elegance of the dress and the polish of the hair.

In the case of the Palazzo del Tè, Gombrich's interpretation of the emotional values of Giulio forging the abstract classicist lexicon into conflicting solutions, and his psychological interpretation of Giulio's use of the bugnato, the rustic order, and the falling stones as an expression of the collapse of an entire architectural system and a society, are closely linked to that other 'modern movement', which was in the very same years rapidly changing, not so much our physical environment, but the interpretations of our own psychological constructions. The interpretation of Mannerism has long been indebted to that confluence of art history and psychology. For some later scholars Mannerism understood in this sense is a modernist invention. John Shearman, for instance, in his Mannerism of 1967, will counter Gombrich's views with a much more "relaxed" reading (Shearman's own word). ${ }^{38}$ For Shearman, "the expectation of an effect of 'tension"' is a product of the modern mind. ${ }^{39}$ Against these modernist readings, Shearman denies the presence of stress and strain in the facial features of la Panciatichi, where he would see instead only maniera in the sense of style, elegance, refinement and sophistication. And as for Giulio's idiosyncrasies, he proposes a 'flattening' of his solutions into inevitable consequences of building conditions and 
patronage - the result of the abandonment of the building site by the duke, and consequently a 'quick and rough', more approximate and cheaper completion by the architect. ${ }^{40}$ But that, of course, is matter-of-fact 1960s Mannerism-should we call it post-modernist?- as opposed to Gombrich's modernist, Freudian 1930s Mannerism.

The Modern Humanist Architect: Wittkower's Michelangelo

In the same year as Gombrich wrote on the Palazzo del Tè, Rudolf Wittkower in 1934 published his seminal article "Michelangelo's Biblioteca Laurenziana" in Art Bulletin. ${ }^{41}$ It was his first article written in English, published in the year of his arrival to the Warburg Institute in London from a by then Nazi-controlled Cologne. Only a year before the Institute itself had moved to London from Hamburg; Gombrich was to arrive, from Vienna, in 1937. After a very detailed and lengthy, eighty-page analysis of the Biblioteca Laurenziana, the article seemed to conclude by addressing a larger audience, outside architectural history's inner circle. ${ }^{42}$ In the final paragraph, 'The Ricetto and the Problem of Mannerist Architecture', Wittkower observes characteristics, and even uses a vocabulary similar to that of Gombrich: "It is evident from the preceding investigation that the insoluble conflict, the restless fluctuation between opposite extremes, is the governing principle of the whole building. What holds for the form of the whole room, holds also for the individual parts of the architecture." ${ }^{43}$ As such, for Wittkower, the Laurenziana is representative of "a big group of buildings arranged on similar principles, common between 1520 and 1580/90 and to be called Mannerist". ${ }^{4}$ Yet it is distinct from Renaissance and Baroque architecture: "The unrelieved tension inherent in the building both as a whole and in detail compels us to separate it alike from the fundamentally tensionless static buildings of the Renaissance, and from the dynamic buildings of the Baroque - whose inherent conflict finds repose within the building itself." 45 Wittkower sees conflict, but also a reversal of roles, double-function, instability:

In no architecture, however, has the idea of conflict been carried through in so new and individual a manner, and with such relentless consistency as in the anteroom of the Laurenziana. Michelangelo has submitted the whole building, in general as in detail, to the idea of conflict. If the Ricetto deserves in this respect a particular place in the history of architecture, it is nevertheless clear from all its features that Michelangelo in this building made himself the supreme representative of a style appearing everywhere during these years, a style the particular character of which is as distinct from Renaissance as from Baroque. ${ }^{46}$

These observations are written both in the aftermath of the first, devastating technological war, and within a European context of sprawling Nazism and fascism. With a generation of young art and architecture historians, Wittkower turns against the legacy of the eighteenth and nineteenth centuries. Against its positivism, pluralism and relativism they feature the spiritual, comprehensive and eternal qualities of humanism; against the pettiness of the European nineteenth and early-twentieth-century bourgeois they show the neo-platonic idealism and the sophistication of the prince and the learned elite at the sixteenth-century courts. Wittkower has this in common with Erwin Panofsky (who had left Germany for the United States a year before Wittkower), with 
the Italian historian Eugenio Garin, with the Romanian (but during the 1930s also London-based) prince, poet and mathematician Matila Ghyka, who had just published Esthétique des Proportions (1927) and Le nombre d'or (I93I), ${ }^{47}$ and with the sociologist Norbert Elias (another German refugee in London), whose 1925 Habilitation was on the Florentine court society: Die Bedeutung der Florentiner Gesellschaft und Kultur furr die Entstehung der Wissenschaft. For all of these scholars this choice "meant a preference for the conception of an open world, discontinuous and full of contradictions, incessantly changing and hostile to any systematization", as Garin would later write in Der italienische Humanismus (1947). ${ }^{48}$

Within such a construct, Mannerism's recently acquired features could easily be connected with the characteristics and demands of the 'modern', progressive part of society in the 1920s and 30s. The 'new style' had from the beginning, in Schmarsow's Barock und Rokoko of 1897, been associated with "freedom" as opposed to Renaissance "severity". ${ }^{49}$ Now, for Wittkower, Mannerist architecture, with its deviations from the norm, with its heresies with respect to the framework of Renaissance, contained both the contradictions and conflicts, and the Platonic basis on which they had been constructed. "When they chose Plato", Garin continues, "they chose, in opposition to all systematizations, the new spirit of research, unprejudiced and truly free. It was like a declaration of war on the oppressively closed, hierarchical and finite world of Aristotle." ${ }^{50}$ Or, in the words of Panofsky in the first pages of The History of Art as a Humanistic Discipline (1937), "from the point of view of authoritarianism, [the humanist] is either a heretic or a revolutionary (or a counterrevolutionary)". This is followed by his well-known words: "the humanist, then, rejects authority. But he respects tradition." 51

The context for understanding Wittkower's work, and its success among modern architects, and especially the success of his Architectural Principles in the Age of Reason (1949), is not, of course, limited to art history and politics. It seems particularly relevant in an architectural context that Wittkower's opposition, like Gombrich's, against the Wölfflinian concept of Zeitgeist replaces the figure of the learned and sensitive yet relatively passive architect driven forth by, or at best surfing on, the Zeitgeist, by an active, albeit sometimes impassioned, designer-intellectual. Wittkower's and Gombrich's Mannerist architect, with his humanist background, with his highly personal emotional and intellectual reactions, debonair yet with the ambition to renew and break rules, keen on conflict and fighting totalitarian styles, is exactly the man that every architect of the Modern Movement would want to be - as opposed to his rule-obeying Beaux-Arts colleague. ${ }^{52}$ To the modernist architect, Wittkower's Michelangelo and Gombrich's Giulio is what Eric Hobsbawn would call an invented tradition.

\section{Saving Modernism: Colin Rowe’s Mannerist Modern Movement}

Mannerist architecture remained prominently present in the immediate post-war publications of the major architectural historians: Pevsner's article 'The Architecture of Mannerism' was published in 1946 and Blunt's 'Mannerism in Architecture' followed three years later. ${ }^{53}$ But it was particularly the modernist matrix of Wittkower's reading 
of sixteenth-century architecture that was eagerly picked up by a generation of architects, who started using Architectural Principles alongside the Modulor - as did the Smithsons. ${ }^{54}$ Among them, Colin Rowe, an architect and pupil of Wittkower's at the Warburg Institute, most clearly saw the implications of the book for the interpretation and further development of modern architecture. In March 1947, shortly following his teacher's 'Principles of Palladio's Architecture' (published in two parts in 1944 and 1945), ${ }^{55}$ but two years before Architectural Principles, Rowe published 'The Mathematics of the Ideal Villa' in the Architectural Review. ${ }^{56}$ Pairing the syntactical devices in the work of (Wittkower's) Palladio to those of Le Corbusier by confronting the Villa Malcontenta with the Villa Stein, he discovered similar compositional strategies. As Alina Payne has argued, "this concentration on syntax allow(ed) him not only to bring Palladio within the orbit of modern criticism, but, more generally, to offer implicitly a strategy for appropriating historical examples into modernist design without openly questioning its programmatic rejection of such borrowing." 57

Rowe's article was followed by another, published three years later, again in the Architectural Review: 'Mannerism and Modern Architecture'. ${ }^{58}$ Rowe cited both Pevsner and Blunt, seemingly as his only sources on Mannerism, while he curiously omitted any reference to his teacher. 'Mannerism and Modern Architecture' starts with an 'outing': Rowe shows Le Corbusier's first considerable project, which the master himself had censured out of his Fuvre complète: the Villa Schwob at La Chaux-de-Fonds of 1916. He points to the blank central surface, for which he cannot find any functional reason and of which he presumes it was "intended to shock". ${ }^{9}$ Following this, Rowe remarks that this feature is not uncommon among sixteenth-century façades, and he mentions the "characteristic late Mannerist schemes" of the so-called Casa di Palladio in Vicenza and Federico Zuccheri's casino in Florence. ${ }^{60}$ However, Rowe avoids direct affiliations, using Wölfflinian juxtaposition rather than derivation, and concludes that "such a correspondence may be purely fortuitous or it may be of deeper significance."61 A couple of pages further on, Rowe hints at what that deeper significance might consist of: "If in the sixteenth century Mannerism was the visual index of an acute spiritual and political crisis, the recurrence of similar propensities at the present day should not be unexpected nor should corresponding conflicts require indication." 62

From the French hero of the Modern Movement, Rowe moves to the Viennese polemicist Adolf Loos. Pausing before Loos's most radical façade, the garden side of Haus Steiner, the historian maliciously remarks that "Loos, with his fanatical attacks upon ornament, might possibly, from one point of view, be considered as already showing Mannerist tendencies ..." unauthorized youthful work, as was the case with Le Corbusier's early villa, but to two, if not canonical in any case largely mediatized examples of avant-garde modernism. Considering Walter Gropius's Bauhaus building, Rowe observes that the logic and structure of the building is not immediately recognizable, as modernist rule would require, but becomes intelligible to the eye only in the 'abstract' view from the air. ${ }^{64}$ "In this idea of disturbing, rather than providing immediate pleasure for the eye" Rowe sees connections with Mannerism: 
Sixteenth century Mannerism is characterized by similar ambiguities; [...] a deliberate and insoluble complexity might be thought to be offered equally by Michelangelo's Cappella Sforza and Mies van der Rohe's project of 1923 for the Brick Country House. In the Capella Sforza, Michelangelo, working in the tradition of the centralized building, establishes an apparently centralized space; but, within its limits, every effort is made to destroy that focus which such a space demands. ${ }^{65}$

The Cappella Sforza "ensues not so much ideal harmony as planned distraction", while the Brick House "is without either conclusion or focus". In its plan "the disintegration of the prototype is as complete as with Michelangelo". ${ }^{66}$

Mannerist organisations in plan link, for Rowe, Mies's Hubbe House of I935 and Vignola and Ammanati's Villa Giulia, ${ }^{67}$ while another Mannerist device, the discord between elements of different scale placed in immediate juxtaposition "is employed, alike, by Michelangelo in the apses of St. Peter's and, with different elements, by Le Corbusier in the Cité de Refuge." ${ }^{\circ 8}$ And Rowe makes, obviously, reference to Le Corbusier's "éloge" (Rowe's word) of St. Peter's in Vers une architecture. According to Rowe, "it is particularly the space arrangements of the present day which will bear comparison with those of the sixteenth century [...]", while "in the vertical surfaces of contemporary architecture, comparison [...] is perhaps of a more superficial than clearly demonstrable order." ${ }^{69}$ Nevertheless, in a numerously held lecture of unknown but slightly later date, 'The Provocative Façade: Frontality and Contrapposto', ${ }^{70}$ Rowe uses the same façade comparisons - and adds one: he cuts out the central part of the façade of Le Corbusier's Villa Stein at Garches, and places it next to Ligorio's casino of Pius IV (or Villa Pia, as he calls it) - the subject, one should recall, of that earliest of articles on Mannerist architecture, Friedländer's of 1915. Rowe: "Shave Villa Pia, crop Garches, and there is stylistic convergence? There certainly is."71

Moreover, in the same text Rowe quotes Le Corbusier to show the extent to which the modern master has an exquisitely Mannerist attitude towards the arts: “...there is a quotation of himself [Le Corbusier] which might help to correct accusations of pedantry: 'In a complete and successful work of art there is a wealth of meaning only accessible to those who have the ability to see it, in other words to those who deserve it."72 This elitist attitude is exactly what distinguishes the Mannerist artist from his Renaissance and Baroque colleagues. Yet, let us turn back to the buildings themselves. Not only an elitist attitude, not only plan and façade compositions link the masters of the sixteenth and the twentieth centuries: towards the end of "Mannerism and Modern Architecture" Rowe addresses the brutalist's choice of materials and modernist detailing: "However, in the present-day choice of texture, surface and detail, aims general to Mannerism might possibly be detected. The surface of the Mannerist wall is either primitive or overrefined; and a brutally direct rustication frequently occurs in combination with an excess of attenuated delicacy."73 This creative tension between brutalism (aka bugnato) and sophistication is, as we have seen, exactly the core of Gombrich's argument in his seminal study on Palazzo del Tè. Rowe continues:

In this context, it is frivolous to compare the preciosity of Serlio's restlessly modelled, quoined designs with our own random rubble; but the frigid 
architecture which appears as the background to many of Bronzino's portraits is surely balanced by the chill of many interiors of our own day. And the linear delicacy of much contemporary detail certainly finds a sixteenth-century correspondence. $^{74}$

In this quotation Rowe allows us to understand his agenda. In 'Mannerism and Modern Architecture' and in the 'The Provocative Façade' that agenda is not only - as was the case in his "Mathematics of the Ideal Villa" - about countering "the avantgarde aura of Le Corbusier's architecture by showing how ingeniously and eclectically one of the most polemical modernists had appropriated and recontextualized the Classical tradition" and about undercutting "modernism's claims to being a schismatic break with the past". ${ }^{75}$ What then, is Rowe's agenda? Surely, it does not concern the opposition of the ingenuity and delicacy of cinquecento architecture to a presumed lack of both in the buildings of the modern masters, as Leon Satkowski seems to suggest in the introduction of the book he wrote with the (then late) Rowe. ${ }^{76}$ Rather, Rowe is defending modernism, as he makes unmistakably clear towards the end of 'The Provocative Façade': “... if nowadays Le Corbusier is becoming distinctly persona non grata, to fail to register his achievement is quite as completely stupid as was the eighteenth-century failure to 'see' either Michelangelo or Borromini — within which succession (...) Le Corbusier assuredly belongs." $" 77$

In 'Mannerism and Modern Architecture', Mannerist qualities — the "delicacy of detail", etc. - are brought to the rescue of modernist, avant-garde architecture. This can be better understood if one takes into consideration a 195I article by a young Polish émigré architect in the United States, Matthew Nowicki, which Rowe would subsequently credit. ${ }^{78}$ In 'Origins and Trends in Modern Architecture' Nowicki wrote:

I suspect that I shall no longer provoke you as much as I should by opening with a statement that sometime ago, our design became a style. [...] A style, with all the restrictions, disciplines, limitations, and blessings that we usually associate with the term. [...] We cannot keep on pretending that we are able to solve our problems without a precedent in form. We have to realize that in the overwhelming majority of modern design, form follows form and not function. ${ }^{79}$

At the very moment when modernism is trading its revolutionary, heretic status for mainstream practice, in those early years of the 1950s when the failures of the Modern Movement are about to be widely discussed, it is, again, Mannerism that is brought into position. That is: at the very moment that modernism's “delicacy of detail”, its formal complexities and contrapposti, all so well-appreciated by Rowe, are watered down into the "rubble" of post-war mass building production.After Mannerism had been a reference point for the early appreciation of Expressionist art by Dvoràk and Friedländer; after Burckhardt (with opposite intentions) had recognised - and feared - in Michelangelo the prototypical modern artist; shortly after the complex attitudes of cinquecento architects had been explored with a positive bias originating in psychoanalysis; and following the Modern Movement architect's modelling after its Mannerist ancestor, Rowe, at last, is steering that same Mannerism to the rescue of modernism. 


\section{Notes}

'Between 1883 and 1889 four volumes came out in the series 'Geschichte der neuren Baukunst': Cornelius Gurlitt, Das barock- und rococo-Ornament Deutschlands. Berlin, E. Wasmuth, 1883. - Id, Geschichte des Barockstiles, des Rococo, und des Klassicismus in Belgien, Holland, Frankreich, England. Stuttgart, Ebner \& Seubert, 1886. — Id., Geschichte des Barockstiles in Italien. Stuttgart, Ebner \& Seubert, 1887. — Id., Geschichte des Barokstiles und des Rococo in Deutschland. Stuttgart, Ebner \& Seubart, 1889.

${ }^{2}$ Heinrich Wölfflin, Renaissance und Barock: Eine Untersuchung über Wesen und Entstehung des Barockstils in Italien. München, T. Ackermann, 1888. Here quoted from the English transl.: Renaissance and Baroque. London: Collins, 1964; p. 145.

${ }^{3}$ Wölfflin I888 (1964): I64, n. 2.

${ }^{4}$ Alois Riegl, Die spätrömische Kunstindustrie. Vienna, K. K. Hof- und Staats-druckerei, 190I. - Id., Die Entstehung der Barockkunst in Rom. Vienna, Anton Schroll, 1908.

${ }^{5}$ Max Dvorák, Über Greco und den Manierismus, in: Kunstgeschichte als Geistesgeschichte. München, 1924; pp. 26I-276. Abridged English ed.: On El Greco and Mannerism, in 'The Magazine of Art', 1953, 46, no. I; pp. I4-23. More recently published in Gert Schiff, ed., German essays on art history, New York, Continuum, 1988; pp. 191-205.

${ }^{6}$ Dvorák 1924:275-276.

${ }^{7}$ The relationships between Mannerist and Baroque art and contemporary religious movements were debated in the 1920s: W. Weisbach, Der Barock als Kunst der gegenreformation, Berlin, 1921. - W. Weisbach, Gegenreformation-Manierismus-Barock, in Repertorium für Kunstwissenschaft', 1928, XLIX. - N. Pevsner, Gegenreformation und Manierismus, in 'Repertorium für Kunstwissenschaft', 1925, XLVI.

${ }^{8}$ Walter Friedländer, Die Entstehung des antiklassichen Stiles in der italienischen Malerei um 1520, in 'Repertorium für Kunstwissenschaft' 46 (1925): 49-86. And: Id., Der antimanieristische Stil um 1590 und sein Verhältnis zum übersinnlichen, in 'Vorträge der Bibliothek Warburg' 1928-1929 (1930): 214-43. Here quoted from the later English book edition: Mannerism and Anti-Mannerism in Italian Painting. New York, Columbia University Press, 1957; p. 48. On Friedländer's position, see Donald Posner, in the foreword of that Eng. ed.

${ }^{9}$ Friedländer 1957:6-7.

${ }^{10}$ Patricia A. Emison, Creating the 'Divine' Artist; From Dante to Michelangelo. Leiden, Brill, 2004; p. 52.

"Werner Weisbach, for instance, in Der Manierismus of 1919, while taking a negative stance on Mannerism, stressed its abstracting mentality. Weisbach, Der Manierismus, in 'Zeitschrift fur bildende Kunst, I915, XXX.

${ }^{12}$ Walter Friedländer, Das Kasino Pius dsr Vierten, in: 'Kunstgeschichtliche Forschungen', (Leipzig) 1912, III.

${ }^{13}$ Erwin Panofsky, Die Scala Regia im Vatikan und die Kunstsammlungen Berninis, in 'Jahrbuch der Preuß. Kunstsammlungen, 1919, XL, pp. 240 ff. 
${ }^{14}$ NikolausPevsner, Gegenreformation und Manierismus, in 'Repertorium für Kunstwissenschaft', 1925, XLVI. — N. Pevsner, Leipziger Barock. Dresden, Wolfgang Jess, 1928. - These studies were followed by another on Italian Mannerist and Baroque painting: N. Pevsner, Die italienische Malerei vom Ende der Renaissance bis zum ausgehenden Rokoko, 1928-32. — On Pevsner's early years, cf.: Ute Engel, The formation of Pevsner's art history: Nikolaus Pevsner in Germany 1902-1935, in: Peter Draper, ed., Reassessing Nikolaus Pevsner. Aldershot, Ashgate, 2004; pp. 29-55, esp. pp. 34 ff. ${ }^{15}$ E. Panofsky, Das erste Blatt aus dem 'Libro' Giorgio Vasaris..., in 'Städel-Jahrbuch, 1930, 6; pp. 25-72. Engl. transl. in Meaning in the Visual Arts. Chicago : University of Chicago Press, 1955. Moreover, in Idea. Ein Beitrag zur Begriffgeschichte der alteren Kunsttheorie, Hamburg: (Studien der Bibliothek Warburg, Nr. 5) 1924, Panofsky had already shown the anti-naturalistic value of the Idea in sixteenth-century literature.

${ }^{16}$ Ernst Michalski, Das Problem des Manierismus in der italienischen Architektur, in 'Zeitschrit für Kunstgeschichte', 1933; pp. 88 ff. See also the small dissertation by Loni Ernst, Manieristische Florentiner Baukunst (Diss.), Potsdam, 1934. Hans Hoffman, Hochrenaissance, Manierismus, Frühbarock, Die italienische Kunst des I6. Jahrhunderts. Zürich-Leipzig, 1938. Cf. the short comments by M. Tafuri, L'architettura del Manierismo nel '500 europeo. Roma, Officina, 1966; esp. Pp. 17-18.

${ }^{17}$ A. Payne, Architectural History and the History of Art: A Suspended Dialogue, in 'The Journal of the Society of Architectural Historians', 1999, Vol. 58, No. 3; pp. 292-299; here p. 294. - S. Giedion, Bauen in Frankreich Eisen Eisenbeton. Leipzig \& Berlin, Klinkhardt \& Biermann, 1928.

18 "Michelangleo is the man of our last thousand years, as Pheidias was the man of the preceeding milennium". Le Corbusier, Vers un architecture. Paris, G. Cres, 1923; p. 133. (Eng. transl. in Towards a New Architecture. Los Angeles, Getty, 2007; p. 205.) Le Corbusier refers to Michelangelo at various occasions in the book, see for instance the tracé régulateur on a photograph of the Campidoglio (pp. 59-60).

${ }^{19}$ Burckhardt names also Tintoretto, Correggio and Rembrandt who had been unable to control their artistic impulse. Rubens, on the contrary, was the modern artistic success because Rubens had been able to channel his artistic will into vast and complete artistic production.

20 "The work of Michelangelo is a creation, not a revival (...)", and: "Like man, like drama, like architecture." Le Corbusier 1923:134; resp. 132-133. Eng. In Le Corbusier 2007:206, resp. 205.

${ }^{21}$ Colin Rowe, Mannerism and modern architecture, in 'Architectural Review', 1950, May; pp. 289-299; here quoted from C. Rowe, As I was saying. Cambridge (Mass.), MIT, I999; vol. I, pp. 29-57; here p. 5 I.

${ }^{22}$ Ernst Gombrich, Mannerism: the historiographical background (1961), in: E. Gombrich, On the Renaissance. London, Phaidon, 1998; vol. I, pp. 99-106; here p. 103.

${ }^{23}$ Theo Van Doesburg, Klassiek-Barok-Modern. Antwerpen, De Sikkel, 1918.

${ }^{24}$ Rowe 1950 (1999): 5 I.

${ }^{25}$ Charles-Edouard Jeanneret [Le Corbusier], Le Renouveau dans l'architecture, in 'L'Oeurre. Organe officiel de la Fédération des Architectes Suisses et de l'Association Suisse romande de l'Art et de l'Industrie', I914, I, no. 2; p. 34: "Nos Romains, nos Gothiques, nos Louis XIV, ce sont maintenant les ingénieurs." 
${ }^{26}$ Pevsner would label the Palazzo del Tè as a "deliberate attack on the Renaissance ideal of the isolation and balance of all parts". Cit. in Egon Verheyen, The Palazzo del Te: In defense of Jacopo Strada, in: 'JSAH', 1972, XXI, 2; pp. I33-I37, here p. 133.

${ }^{27}$ Wolfgang Lotz, Mannerism in Architecture: Changing Aspects, in: 'Acts of the XX International Congress of the History of Art'. Princeton, 1963, II, pp. 239-246; here p. 240.

${ }^{28}$ E. Gombrich, Zum Werke Giulio Romanos: I. Der Palazzo del Te, Jahrbuch der Kunsthistorischen Sammlungen in Wien, 1934, N.F. 8; pp. 79-104. And, Id., Zum Werke Giulio Romanos: 2, Versuch einer Deutung, Jahrbuch der Kunsthistorischen Sammlungen in Wien, 1935, N.F. 9; pp. 121-I50.

${ }^{29}$ E. Gombrich, Review of Egon Verheyen, 'The Palazzo del Tè in Mantua, Images of Love and Politics', in Burlington Magazine, Vol. 122, 1980; pp.70-7I. My italics. Full quotation: "When I first visited Mantua as a student my head was full of debates about the status and meaning of 'Mannerism' in sixteenth-century art. Being startled by the Palazzo del Tè I was surprised to find that it had not yet been mentioned in these discussions and that in particular Giulio Romano's building designs had been completely neglected. This was before Rudolf Wittkower had published his seminal paper of 1934 on the Laurenziana as a document of Mannerist aesthetics, and the question whether or not the term Mannerism could be usefully applied to architecture was still sub judice. Julius von Schlosser readily accepted the thesis subject of 'Giulio Romano als Architekt' and I found to my satisfaction that much of what I had read about the alleged anti-classical style applied to many of Giulio's bizarre designs, while others seemed to me to be almost ostentatiously restrained and classical. I made much of this tension and of what it appeared to signify in psychological terms, though I explicitly rejected the recourse to the 'spirit of the age' as an explanation of these characteristics."

${ }^{30}$ Cf. Richard Woodfield, Gombrich and Psychology, in: Paul Smith and Carolyn Wilde (eds.), A Companion to Art Theory. Oxford, Blackwell, 2002; pp. 426-435.

${ }^{31}$ Unedited typoscripted registration of Manfredo Tafuri's course Corso di Storia dell'architettura 2A: Giulio Romano, of I5 Nov. 1985 p. 3. My translation.

${ }^{32}$ Kurt Forster and Richard Tuttle, The Palazzo del Te, in 'JSAH', I 97I, XXX, 4; p. 267.

${ }^{33}$ Sigmund Freud, Eine Kindheitserinnerung des Leonardo da Vinci (I9/0), in: G.W. XII, Fisher Verlag, Frankfurt 1968 (Vierte Auflage); pp. 128-2II.

${ }^{34}$ The young Gombrich attended the lectures of the psychologist and semiotician Karl Bühler and participated in his students' experiments; cf. Woodfield 2002:426. — Kris was close to Gombrich: he would author with him a book on caricature (eventually only published in a much abbreviated form in 1940), and as the alliance between Hitler's Germany and Austria grew stronger, it was Kris who recommended Gombrich for a position at the Warburg Library. - Gombrich will later explicitly refer to Freud: cf. Ernst Gombrich, Psycho-Analysis and the History of Art, 1953, repub. in Meditations on a Hobby Horse and Other Essays on the Theory of Art. London, 1963. - Ernst Gombrich, Freud's Aesthetics, in: 'Encounter', 1966, XXVI; pp. 30-40.

${ }^{35}$ Sigmund Freud (hrsg.), 'Imago. Zeitschrift für Anwendung der Psychoanalyse auf die Geisteswissenschaften'. Wien, Internationaler psychoanalytischer Verlag, 1923-33, 193537. As of vol. 19 the title changed in 'Imago. Zeitschrift für psychoanalytische Psychologie, ihre Grenzgebiete und Anwendungen'. 
${ }^{36}$ See a.o. Kris's article on the drawings of the $14^{\text {th }}$ century Italian cleric Opicinus de Canistris: Ernst Kris, A psychotic artist of the Middle Ages (1936), in: Ernst Kris, Psychoanlaytic Explorations in Art. New York, International Universities Press, 1952; pp. II8-127.

${ }^{37}$ James Mirollo in Franklin Robinson \& Stephen Nichols (eds.), The Meaning of Mannerism. Hanover, University Press of New England, 1972.

${ }^{38}$ John Shearman, Giulio Romano, by Frederick Hartt (book review), in 'Burlington Magazine', 1959, I0I; p. 460.

${ }^{39}$ Shearman 1959:460; italic in the text.

${ }^{40}$ John Shearman, Osservazioni sulla chronologia e l'evoluzione del Palazzo del Te, in 'Bollettino del centro internazionale di studi di architettura Andrea Palladio, 1967, IX; pp. 434438. - One can find an argument against this position in the fact that the same contrast rustico-raffinato can be found in the painted architecture; for instance in the villa vescovile di Quingentole, cf. Giulio Romano (cat. Mantova). Milano, Electa, 1989: ill. on 218 , and 524-525.

${ }^{41}$ Rudolf Wittkower, Michelangelo's Biblioteca Laurenziana, in 'Art Bulletin', XVI, 1934, Pp. 123-2|8.

Later republished in Idea and Image, 1978. It followed Wittkowers's article on the dome of the Saint Peter's of 1933.

${ }^{42}$ Originally Wittkower seems to have intended to preface the article with a now lost section, written a year before as Das Problem manieristischer Architektur, from which he most likely uses elements in the conclusion. The text was part of an unpublished typescript Festschrift für Walter Friedländer zum 60. Geburtstag am 10.3.1933. Cf. Margaret Wittkower, Foreword to Rudolf Wittkower, Idea and Image; Studies in the Italian

Renaissance. London, Thames and Hudson, 1978. p. 8.

${ }^{43}$ Wittkower 1934:206; my italics.

${ }^{44}$ Wittkower 1934:216.

${ }^{45}$ Wittkower 1934:215-216.

${ }^{46}$ Wittkower 1934:213.

${ }^{47}$ Wittkower, and after him Rowe, will later refer to Ghyka's explorations of the Golden Section in M. Ghyka, The geometry of art and life. New York, Sheed and Ward, 1946.

${ }^{48}$ Eugenio Garin, Der italienische Humanismus. Bern, Francke, 1947. The text was first published in German, from the Italian ms., and only later, in 1952, in Italian. Here cited from the Engl. transl., Italian humanism; philosophy and civic life in the Renaissance. New York, Harper \& Row, 1965; pp. I0-II.

${ }^{49}$ August Schmarsow, Barock und Rokoko, eine Auseinandersetzung über das Malerische in der Architektur. Leipzig, Hirzel, I897; p. 46.

${ }^{50}$ Garin 1947 (1965): I0-II.

${ }^{51}$ Erwin Panosky, The History of Art as a Humanistic Discipline (1937), later published as the introduction to: Meaning in the visual arts: papers in and on art history. Garden City, N.Y., Doubleday, 1955; p. 3. - In a rather sarcastic footnote to the same article, Panofsky refers to the importance of Plato within the context of 1930's politics: "Needless to say, the works of "Plato and other philosophers" also play an anti-Fascist role "in such circumstances." Panofsky 1937 (1955):23, n. I 8. Panofsky is actually reacting 
against the accusation that the study of "Plato and other philosophers" plays an antiMarxist role. The whole footnote reads as follows: "In a letter to the New Statesman and Nation, XIII, 1937, June 19, a Mr. Pat Sloan defends the dismissal of professors and teachers in Soviet Russia by stating that "a professor who advocates an antiquated prescientific philosophy as against a scientific one may be as powerful a reactionary force as a soldier in an army of intervention." And it turns out that by "advocating" he means also the mere transmission of what he calls "pre-scientific" philosophy, for he continues as follows: "How many minds in Britain today are being kept from ever establishing contact with Marxism by the simple process of loading them to capacity with the works of Plato and other philosophers? These works play not a neutral, but an anti-Marxist role in such circumstances, and Marxists recognize this fact." Needless to say, the works of "Plato and other philosophers" also play an anti-Fascist role "in such circumstances," and Fascists, too, "recognize this fact"."

${ }^{52}$ In a critical remark following Anthony Blunt's lecture on Mannerism at the RIBA (later published as Anthony Blunt, Mannerism in Architecture, in 'Journal of the RIBA', March 1949; pp. 195-200), Peter Smithson seems to react on this perception. Smithson "wondered whether those with Academic training who then inverted the system, nevertheless retained something of their original academicism." Cited in Anthony Vidler, Histories of the immediate present: inventing architectural modernism, 1930-1975.

Proefschrift (PhD), Technische Universiteit Delft, 2005; p. 248, note cxxxvi. Later published as Histories of the immediate present: inventing architectural modernism. Cambridge, MA, MITPress, 2008.

${ }^{53}$ Nikolaus Pevsner, The Architecture of Mannerism, in Geoffrey Grigson (ed.), The Mint: A Miscellany of Literature, Art and Criticism, London, Routledge, 1946; pp. I 16-138; which would later be included in his An Outline of European Architecture. As we mentioned earlier, Pevsner had a pioneering role, in the mid 1920's, in developing the concept of Mannerism in architecture. - And Blunt 1949.

${ }^{54}$ See the Smythsons' defense of Wittkower's study in their 1952 letter in reaction to a very negative review in the RIBA Journal: the letter appeared later in 'Arena', February 1966, p. 182; cit. in: Henry A. Millon, Rudolf Wittkower, 'Architectural Principles in the Age of Humanism': Its Influence on the Development and Interpretation of Modern Architecture, JSAH, 1972, XXXI , (pp. 83-91); p. 89.

${ }_{55}$ Rudolf Wittkower, Principles of Palladio's Architecture Part I, in 'Journal of the Warburg and Courtauld Institutes', 1944, 7, pp. 102-122, and Part II, in 'Journal of the Warburg and Courtauld Institutes', 1945, 8; Pp. 68-106. Both texts were incorporated in Architectural Principles in the Age of Humanism (1949).

${ }^{56}$ Colin Rowe, The Mathematics of the Ideal Villa: Palladio and Le Corbusier Compared, in 'Architectural Review', 1947, March; later republished in: Colin Rowe, The Mathematics of the Ideal Villa and Other Essays. Cambridge, MA, MIT Press, 1976.

${ }^{57}$ Alina Payne, Rudolf Wittkower and Architectural Principles in the Age of Modernism, in 'JSAH', I994, LIII, 3; pp. 322-342; here p. 339.

${ }^{58}$ Rowe 1950 (1999):34.

${ }^{59}$ Rowe 1950 (1999):31.

${ }^{60}$ Rowe 1950 (1999):32-34.

${ }^{61}$ Rowe 1950 (1999):34. 
${ }^{62}$ Rowe 1950 (1999):43.

${ }^{63}$ Rowe 1950 (1999):40.

64 "at the Bauhaus, while one registers mental appreciation of both plan and structure, the eye is faced witht the disturbing problem of simultaneous impact from widely dispersed elements." Rowe 1950 (1999):45.

${ }^{65}$ Rowe 1950 (1999):45.

${ }^{66}$ Rowe 1950 (1999):49.

${ }^{67}$ Rowe 1950 (1999):49.

${ }^{68}$ Rowe 1950 (1999):50.

${ }^{69}$ Rowe 1950 (1999):49, 50.

${ }^{70}$ Probably first presented c1960, and re-presented at various occasions and with slightly variying titles, but published much later, as: Colin Rowe, The Provocative Façade: Frontality and Contrapposto, in: Le Corbusier: Architect of the Century. London: Arts Council of Great Britain, 1987; pp. 24-28. The text was later also published in: C. Rowe, As I was saying. Cambridge (Mass.), MIT, 1999; vol. 2, pp. I7I-203.

${ }^{71}$ Rowe cl960 (1987):28.

${ }^{72}$ Rowe cl 960 (1987):28.

${ }^{73}$ Rowe 1950 (1999):50, my italics.

${ }^{74}$ Rowe 1950:50.

${ }^{75}$ Joan Ockmann, Form without Utopia: Contextualizing Colin Rowe, in 'The Journal of the Society of Architectural Historians', 1998, vol. 57, no. 4; pp. 448-456; here pp. 449-50. ${ }^{76}$ See Leon Satkowski's acknowledgements, in Colin Rowe and Leon Satkowski, Italian Architecture of the $16^{\text {th }}$ Century. New York, Princeton Architectural Press, 2002; especially Pp. vi-vii. - Rowe died in 1999.

${ }_{77}$ Rowe cl960 (1987):28.

${ }^{78}$ Rowe refers to Nowicki on several pages in: Colin Rowe, 'Neo-Classicism' and Modern Architecture I, in: 'Oppositions', 1973, I; Pp. I-26.

${ }^{79}$ Matthew Nowicki, Origins and Trends in Modern Architecture, in 'The Magazine of Art', November 195 I; pp. $273 \mathrm{ff}$. Nowicki's text is republished in Joan Ockman, ed., Architecture Culture, 1943-1968: A Documentary Anthology. New York, Rizzoli, 1993; pp. 149-156. Ockman refers to this quote in the context of Rowe in Ockman 1998:45 I. On Nowicki, see also: H.F. Mallgrave, Modern Architectural Theory: a historical survey, 16731968. New York, Cambridge University Press, 2005; pp. 339-340. 